\title{
Chediak-Higashi Syndrome in Accelerated Phase Masquerading as Acute Leukemia
}

\author{
Akut Lösemiyi Taklit Eden Akselere Fazda Chediak Higashi Sendromu
}

Mili Jain, Ashutosh Kumar, Uma Shankar Singh, Rashmi Kushwaha

King George's Medical University, Department of Pathology, Uttar Pradesh, India

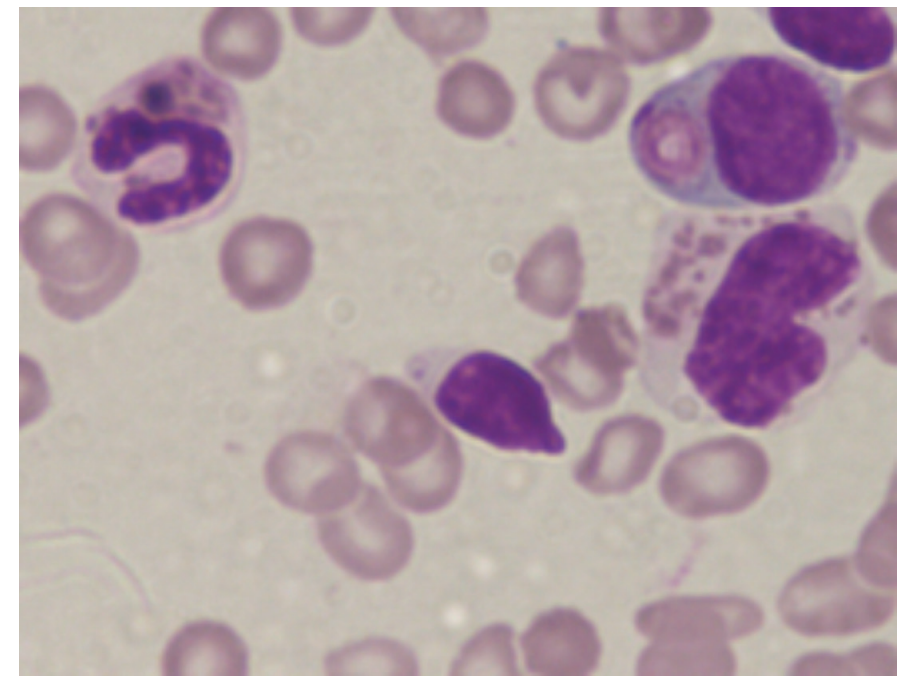

Figure 1. Peripheral blood smear with Leishman stain at 400x: giant granules in neutrophils and lymphocytes.

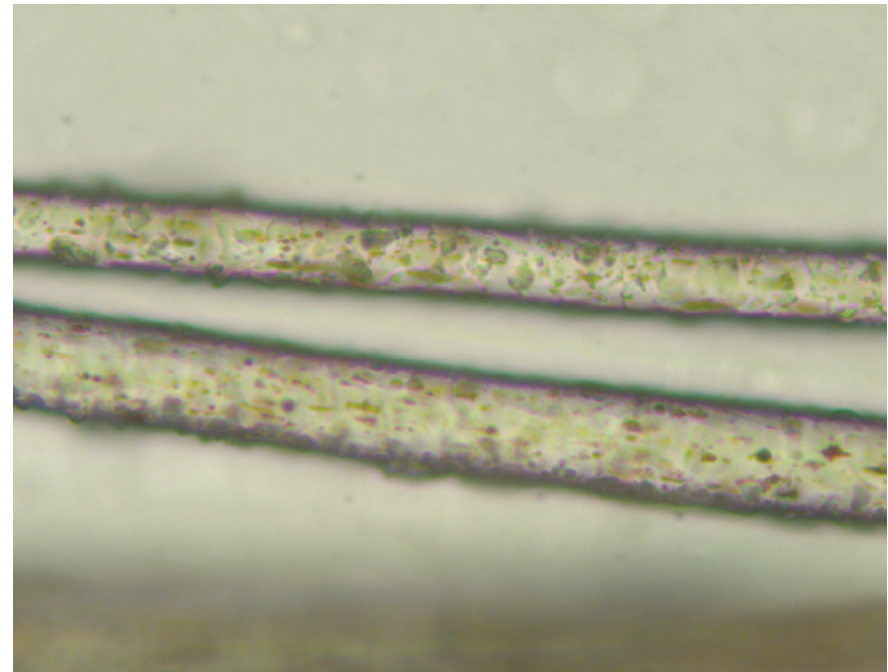

Figure 2. Hair follicles at 400x with irregularly sized melanosomes.
We present a 3-year-old female born of a consanguineous marriage with the complaints of high-grade fever, petechial spots, abdominal distension, and lymphadenopathy for 20 days. She had pallor, hypopigmented hairs, petechial rashes, and palpable lymph nodes (up to $1 \mathrm{~cm}$ ) in the bilateral inguinal and cervical region. Systemic examination revealed hepatosplenomegaly. Her hematological profile was as follows: hemoglobin of $8.4 \mathrm{~g} / \mathrm{dL}$, normocytic normochromic red cell indices, platelet count of $11 \times 10^{9} / \mathrm{L}$, total leukocyte count of $7 \times 109 / \mathrm{L}$ with increased lymphocytes (68.5\%), and lactate dehydrogenase raised at $796 \mathrm{IU} / \mathrm{L}$. The peripheral blood smear examination revealed giant granules in neutrophils, lymphocytes, and monocytes (Figure 1). Bone marrow examination revealed similar granules in myeloid precursors with moderate hemophagocytosis. Examination of the hair shafts showed large melanin granules (Figure 2). Her liver function tests, kidney function tests, and chest X-ray results were within reference ranges. She was diagnosed with ChediakHigashi syndrome (CHS) in the accelerated phase.

CHS is a rare autosomal recessive disorder (gene CHS1/LYST) [1]. The clinical picture includes partial oculocutaneous albinism, abnormal bleeding time, peripheral neuropathy, and recurrent severe bacterial infection [2]. The giant lysosomal granules (formed as a result of cytoplasmic injury, phagocytosis, and fusion due to microtubular defects) in white blood cells are pathognomonic for diagnosis [3]. 
Keywords: Chediak Higashi syndrome, Giant granules, Immunodeficiency

Anahtar Sözcükler: Chediak Higashi sendromu, Dev granüller, İmmün yetmezlik

\section{Authorship Contributions}

Concept: Mili Jain; Design: Mili Jain, Ashutosh Kumar, Uma Shankar Singh, Rashmi Kushwaha; Data Collection or Processing: Mili Jain, Ashutosh Kumar, Uma Shankar Singh, Rashmi Kushwaha; Analysis or Interpretation: Mili Jain, Ashutosh Kumar, Uma Shankar Singh, Rashmi Kushwaha; Literature Search: Mili Jain; Writing: Mili Jain.
Conflict of Interest: The authors of this paper have no conflicts of interest, including specific financial interests, relationships, and/or affiliations relevant to the subject matter or materials included.

\section{References}

1. Antunes $H$, Pereira $A$, Cunha I. Chediak-Higashi syndrome: pathognomonic feature. Lancet 2013;382:1514.

2. Bharti $S$, Bhatia $P$, Bansal D, Varma N. The accelerated phase of ChediakHigashi syndrome: the importance of hematological evaluation. Turk J Hematol 2013;30:85-87.

3. Usha HN, Prabhu PD, Sridevi M, Baindur K, Balakrishnan CM. ChediakHigashi syndrome. Indian Pediatr 1994;34:1115-1119. 